\title{
Are Ministry of Environment Holding Times for Nitrate and Nitrite Tests in Drinking Water Justified?
}

\author{
Vu Nguyen ${ }^{1}$, Helen Heacock ${ }^{2}$, and Kevin Soulsbury ${ }^{3}$ \\ 1 Lead Author, B. Tech Student, School of Health Science, British Columbia Institute of Technology, 3700 Willingdon Ave, Burnaby, V5G 3H2 \\ 2 Supervisor, School of Health Sciences, British Columbia Institute of Technology, 3700 Willingdon Ave, Burnaby, BC V5G 3H2 \\ 3 Contributor, BCIT Chemistry, Columbia Institute of Technology, 3700 Willingdon Ave, Burnaby, BC V5G 3H2
}

\begin{abstract}
Background: Exposure to nitrate and nitrite in high concentration is associated with various health issues in humans such as methemoglobinemia, gastric and bladder cancers. Surface and ground water is vulnerable to nitrate and nitrite contamination which can have a significant impact to communities that use the water for consumption. Methods: Ion chromatography analysis of nitrate and nitrite degradation over time in well water from Abbotsford-Sumas Aquifer was performed in an analytical chemistry study. Nitrate and nitrite test strips marketed for testing drinking water were also used and results were compared to ion chromatography results. Results: Test strips used were unable to detect the level of nitrate/nitrite in the well water sample drawn from the AbbotsfordSumas aquifer. Ion chromatography, IC, methods were able to detect measurable amounts of nitrates which resulted from concentrations of $1.17 \mathrm{mg} / \mathrm{L} \mathrm{NO}_{3}$ as $\mathrm{N}$ to $1.13 \mathrm{mg} / \mathrm{L} \mathrm{NO} \mathrm{N}_{3}$ as $\mathrm{N}$ from day 0 to 31 of the sampling date. The concentration decreased $0.04 \mathrm{mg} / \mathrm{L} \mathrm{NO}_{3}$ as $\mathrm{N}$ over 31 days. Nitrites tested by IC were below the detection limit. Conclusion: In regards to nitrates, the MOE holding times are justified in that the concentrations were statistically different $(p=0.0001)$ from day 0 to day 31 from the sampling date indicating a change of concentration of the chemical due to time. However, the difference was not of a magnitude that may impact public health practices/policies. Test strips comparisons with EPA IC methods were non-conclusive since test strips were unable to detect measurable amounts of nitrate/nitrites. Future studies of nitrate concentrations with respect to chemical and biological components in water may lead to a greater understanding of its change in the environment and thus its association with other potential health hazards.
\end{abstract}

Keywords: Nitrate, nitrite, drinking water, methemoglobinemia, holding times, gastric, bladder, test strips, Ion Chromatography, environmental health, public health, e.coli

\section{Introduction:}

In the Waterloo Region of Ontario, the public health unit launched a private well water testing initiative. In order to help promote nitrate testing for private well owners, the health unit made nitrate test strips available for free of charge. The intent was to have owners test nitrates regularly as nitrates could seep into the drinking water source from malfunctioning septic systems (Cambridge, 2007). Nitrate can come from various sources such as "animal waste, private septic systems, wastewater, flooded sewers, polluted storm water runoff, fertilizers, agricultural runoff and decaying plants” (CDC, 2010). Thus nitrate is an indicator of possible E.coli 0157:H7 contamination due to nitrate and E.coli's association with fecal matter. In an interview with Doug Quibell, manager of environmental health and lifestyle resources in the Waterloo Region at the time (currently the NW Area Manager for Public Health Protection at Northern Health in BC), he stated that exposure to well water with high nitrate concentration can have serious health implications such as sudden infant death syndrome (Cambridge, 2007).

The source of increased nitrate contamination to the environment not only may originate from failing septic systems but could also be associated with the increased amount of agriculture in the latter half of the past century. Fueled by the need for munitions for the German army in World War 1, the mass production of ammonia eventually found wide use in the agriculture industry as a fertilizer. Fertilizer from this anthropogenic process was estimated to provide for a third of all human populations (Wolfe, 2001). Runoff from fertilizers, however, could be a major source of man-made nitrate and nitrite contamination as ammonia oxidizes to these chemical species in the nitrogen cycle (Chang R., Cruickshank B., 2005). The increase of nitrate in the ocean may contribute to marine phytoplankton growth and cause an algae bloom also known as red-tide. The 
effects of red tide can devastate aquatic life and also be a major contributing factor for paralytic, amnesic, and diarrhetic shellfish poisoning. This complex environmental issue with algae blooms in regards to nitrate contamination is just one example of many of which are beyond the scope of this research paper.

Nitrate and nitrite concentrations were listed under the guidelines for Canadian drinking water quality [GCDWQ] (Health Canada, 2012), to have a limit of $45 \mathrm{mg} / \mathrm{L}$ and 3.2 $\mathrm{mg} / \mathrm{L}$ respectively and it should be noted that the approval of these limits occurred in 1987. These parameters were of particular importance in drinking water because exceeding these maximum acceptance concentrations may increase health risks; it has been documented to be associated with infant death from methemoglobinemia (Comly, 1945) as well as induce gastric (McKnight, Duncan, Leifert, \& Golden, 1999) and bladder cancer (Mostafa, Sheweita, \& O’Conner, 1999) in adults.

With public health concerns surrounding nitrate and nitrite it is no surprise that there are several available methods of testing for nitrate and nitrite levels. This study assessed the accuracy of inexpensive nitrate and nitrite test strips marketed for testing drinking water, swimming pool water, and aquarium water by comparing the test strip results with methods used by accredited laboratories as well as to aid in the understanding of nitrate and nitrite change over time in water which may or may not justify the Ministry of Environment (MOE) holding times for these tests.

The purpose of this research paper was to compare the accuracy and precision of nitrate and nitrite test strips commercially available to the general public against an approved EPA method utilizing ion chromatography. In addition, this study also determined if there was a statistical difference between nitrate and nitrite concentrations in an environmental sample after 3 and 31 days from the sampling date to confirm the validity and rationale for Health Authorities to conform to standardized BC Ministry of Environments holding times when sampling.

\section{Literature Review:}

Water is vital in sustaining a healthy life as it is a crucial chemical for metabolic processes in the body. In addition, water provides humans a solvent for other solutes required to sustain life. A water source free of microbiological and chemical contaminates will reduce waterborne disease.

\section{Drinking Water Legislation}

Drinking water systems in British Columbia (BC), are permitted by drinking water officers or delegated health officers as required by the Drinking Water Protection Act ([DWPA], 2013). Moreover, permits have set conditions which need to be met for the water systems to legally operate. These conditions include the number of samples to be taken for testing per month as prescribed by schedule B of the Drinking Water Protections Regulations ([DWPR], 2013). These samples are sent to laboratories which are approved by the provincial health officer for tests to determine if the water is potable or not.

Current regulations in BC's DWPR, Schedule A, entitled "Water Quality Standards for Potable Water” under the DWPA only states microbiological parameters for drinking water (DWPR, 2013). According to regulation, as long as the water contains no E.coli or fecal coliforms per $100 \mathrm{~mL}$ of sample and with a maximum limit $10 \%$ of total coliforms in the samples or less than 10 colony forming units (CFU) per $100 \mathrm{~mL}$ of sample it is considered potable water. Since there are no chemical parameters in this schedule, a sample with toxic levels of nitrates or nitrites could still be considered legally potable as long as the microbiological requirements are met.

Addressing the lack regulations with respect to other parameters mentioned is accomplished through guidelines. Health Canada establishes the GCDWQ (Health Canada, 2012) which includes additional microbiological, chemical, physical, and radiological parameters not covered in provincial legislations. These guidelines are not regulations, however, through BC's Public Health Act ([PHA], 2013) a health officer has the power to declare a health hazard if he or she has significant evidence (e.g. not passing these guidelines) that it may exist. Ultimately, it is the discretion of the officer to take the appropriate actions.

\section{Guideline for Drinking Water Quality (GCDWQ) Criteria of $\mathbf{N} / \mathbf{N}$}

Surface and ground water is vulnerable to nitrate and nitrite contamination which can have a significant impact to communities that use the water for consumption. Maximum allowable concentration (MAC) values for nitrate and nitrite concentrations for drinking water are listed under the GCDWQ (Health Canada, 2012) to have set limit of 45mg/L and $3.2 \mathrm{mg} / \mathrm{L}$ respectively. Alternatively, nitrate and nitrite MAC values can also be listed as $10 \mathrm{mg} / \mathrm{L}$ as $\mathrm{N}$ or $1 \mathrm{mg} / \mathrm{L}$ as $\mathrm{N}$ respectively and these values reflect the same concentration levels as the latter, however, a stoichiometric factor (conversion factor based on molecular weights) has been applied. Levels below these values are considered safe for normal daily consumption. According to the guideline these "Health-based guidelines are established on the basis of comprehensive review of the known health effects associated with each contaminant, on exposure levels and on the availability of treatment and analytical technologies." The GCDWQ (Health Canada, 2012) is therefore a key document for environmental health officers to use in determining health hazards associated with drinking water. 


\section{Enforceable Regulatory Criteria of N/N}

Waste water can contain excessive amounts of nitrate and nitrite contamination depending on the industrial process. Schedule 6 entitled "Generic Numerical Water Standards" in the Contaminated Sites Regulation under the

Environmental Management Act ([EMA], 2013) states that the effluent waste water from these industrial processes must not exceed 10,000 ug/L for nitrate as N, 10,000 ug/L for nitrate and nitrite as $\mathrm{N}$, and 3,200 ug/L for nitrite as $\mathrm{N}$ to protect drinking water. These standards, however, are enforced by conservation officers.

\section{The Health Threat of $\mathbf{N} / \mathbf{N}$}

Direct studies on the health threat of nitrate and nitrite have revealed that nitrite is more toxic than nitrate. When comparing the lethal dosage of the anions, nitrite has a lower LD50. In a study with mice, the LD50 of sodium nitrate and sodium nitrite was 1600-9000 and 85-220 mg per kilogram per body weight of mice, respectively (World Health Organization [WHO], 2011). In humans, nitrate toxicity may be due to its reduction to nitrite. This may be due to nitrites association with disrupting normal hemoglobin formation causing methemoglobinemia and gastric cancers.

Exposure to nitrates in high concentration is associated with various health issues in humans. The transformation of nitrate to nitrite in the body has been associated with gastric (McKnight et. al, 1999) and bladder cancer (Mostafa et. al, 1999). High nitrates in drinking water have been associated to methemoglobinemia, also known as "blue baby syndrome” (Comly, 1945).

Gastric cancer has been associated with nitrites in water which is a product of nitrate reduction. Studies have focused on nitrate-reducing bacteria's ability to reduce nitrates to nitrites in the oral cavity (Isaacson et. al, 1991) which then would increase the production of N-nitrosamines a well known carcinogen in animals (Archer, 1989). However, other studies also have shown that this reduction of nitrites in the oral cavity is beneficial as they are precursors to compounds such as nitric oxides which are important to overall host defense and normal physiological homeostasis (McKnight et. al, 1999).

Bladder cancer is another condition associated with nitrates. Nitrates in urine are normally excreted from the body and no reduction to nitrite usually takes place in healthy individuals. However, there is an increased risk when the individual has a Schistosoma haematobium infection in the bladder (Mostafa et. al, 1999). The mechanism of the chronic infection that has been proposed is that increased nitrate reduction from the parasite enhances carcinogenic $\mathrm{N}$-nitrosamines due to the increase of nitrite concentration in the bladder (Badawi, 2000).
Methemoglobinemia is a condition where about $15 \%$ of hemoglobin has been converted into methemoglobin in the circulatory system (Avery, 1999) leading to symptoms of cyanosis, and an increased risk of death as the percentage of methemoglobin increases. Hemoglobin is converted to methemoglobin through oxidation of the iron group making it unable to exchange oxygen in the body. The human body does produce methemoglobin-reductases to reduce methemoglobin, however, deficiencies of these enzymes does occur in the human population. Infants are a part of the population that lack methemoglobin- reductase and it is not until approximately 6 months from birth that they can produce adult levels of the enzyme (Lukens, 1987).

\section{Previous Research}

Past studies have shown that concentrations of chemical compounds increased after boiling. In one study it was shown that boiling water would increase the concentration of nitrate in the water (Cranch, 2005). In a second study it was shown that arsenic also increased in concentration after it was boiled over a given amount of time. Both of these chemicals can be found in the GCDWQ with maximum acceptable concentrations (MAC) of $45 \mathrm{mg} / \mathrm{L}$ and 0.010 $\mathrm{mg} / \mathrm{L}$ respectively. In the study that showed arsenic increasing, the researcher took environmental drinking water samples a First Nations reserve (Upper Nicola Band) near Merritt, B.C that was on a boiling water advisory (BWA) (Maze, 2007). What was found that without boiling, arsenic levels were within the limits of the guideline; however, after boiling the values were greater than its' MAC (Maze, 2007) which is specifically based on arsenic carcinogenicity. Although in the GCDWQ it states that:
"In general, the highest priority guidelines are those dealing with microbiological contaminants. Any measure taken to reduce concentrations of chemical contaminants should not compromise the effectiveness of disinfection."

Chronic exposures to chemicals over the MAC should be considered in the decision of a BWA in BC especially in those communities that are on long term BWAs.

\section{Abbotsford-Sumas Aquifer}

The Abbotsford-Sumas Aquifer is a ground water source shared by British Columbia and Western Washington that is impacted by agriculture activity and known to have high levels nitrates in rural wells (Ministry of Environment [MOE], 2007). This trans-boundary drinking water source in BC's side is approximately 100 square kilometers between Aldergrove Lake Park and Riverside Road south of the trans-Canada highway and is susceptible to contamination (City of Abbotsford, 2013). According to the MOE the sources of nitrate in this area includes "leaching of chemical fertilizers, leaching of animal manure and groundwater pollution from septic and sewage discharges” (MOE, 2007) 
which are all non-point sources. A study of nitrate in the Abbotsford-Sumas Aquifer found from Western Washington University found levels ranging from 10 to 25 $\mathrm{mg} / \mathrm{L}$ of nitrate indicating that nitrate was transported from BC to Washington State (Mitchell, 2004).

\section{Test strips}

Although there are regulations and guidelines pertaining to nitrate and nitrite concentration limits in drinking water, there are other reasons to test for nitrate and nitrite concentrations in other situations such as in swimming pools. Available diagnostic tools used in some swimming pools are nitrate and nitrite test strips. Aquachek ${ }^{\circledR}$ Nitrate/Nitrite test strips made by Hach are advertised to "Check nitrate/nitrite levels if you are seeing excess chlorine demand. A positive nitrate test also indicates the potential for algae growth. Dip and read test strips give results for both in less than one minute (Aquachek, 2013).” This is a rapid and inexpensive test to test for nitrates for pools.

\section{Industry Best Practice for Sampling}

Both drinking water and waste water samples should be sent to approved laboratories for water quality testing in the appropriate conditions. The BC Ministry of Environment (MOE) has set a 3 day holding time for nitrate and nitrite analysis and this is based on nitrites readily converting into nitrates due to nitrite oxidizing bacteria in water

(Abeliovich, 2007). In addition, the container type should be plastic or glass and be held at less than or equal to $6^{\circ} \mathrm{C}$ during transportation to the laboratory in order slow down the oxidation reaction. Without following these conditions results may not be accurate.

\section{Methods and Materials}

\section{Dionex ICS-2000}

The Dionex ICS-2000 (Dionex, 2008) is an ion chromatography (IC) system which allows for the separation of anions in solution based on differences on individual anion conductivity (measured in $\mu \mathrm{S}$ - micro Siemens) as the sample elutes over a period of time (K. Soulsbury, personal communication, October 24, 2013). Full description of the inner workings of the Dionex ICS-2000 was found in the Dionex ICS-2000 operator's manual.

The Dionex AS40 autosampler, was pre-loaded with multiple samples in rows of cassettes. Each cassette held 6 disposable vials with filter caps containing samples. The autosampler's max capacity was 11 cartridges totaling 66 samples; however, as the sample run progressed more cassettes were added increasing its capacity (K. Soulsbury, personal communication, October 24, 2013). Coupled with the Dionex ICS-2000, once fully loaded, the system was fully automated without supervision. This was practical because each sample took typically 15 minutes each to run (K. Soulsbury, personal communication, October 24, 2013).

\section{HACH ${ }^{\circledR}$ Nitrate and Nitrite Test Strips}

Nitrate and Nitrite test strips are safe, affordable and quick to determine general respective levels in well water. Each test strip has 2 areas to indicate nitrate and nitrite concentration. These areas change colour after submersion of the strip into sample solutions which is then matched to a colour chart that corresponds to concentration. The Hach ${ }^{\circledR}$ website (Hach, 2014) states that the concentration range for each anion is 0-50 and 0-3.0 ppm as $\mathrm{N}$ respectively. Furthermore, the manufacture states that the incremental steps in concentration are $0,1,2,5,10,20,50 \mathrm{ppm} /$ 0, 0.15, $0.3,1,1.5,3$ ppm as $\mathrm{N}$ respectively (Aquachek, 2013). These test strips according to Hach are approved by the Environmental Protection Agency (EPA, 1993).

Disposable test strips for nitrate and nitrite are widely available to determine nitrate and nitrite concentrations in water. Advantages of using test strips is that (a) it is relatively inexpensive (b) it is extremely fast (c) it can be performed in the field and (d) it does not require extensive laboratory training. The fact that it is done in the field removes the transportation issues involved in sending it to the laboratory. The speed of result is great to screen for nitrate or nitrite levels and thus appropriate decisions can be made quickly. Also extensive laboratory training is not required and so this means that the general public is able to quickly ensure nitrate and nitrite levels are acceptable -this is especially useful in remote areas of BC. The disadvantages, however, are that test strips have a limited lifetime (Capitán-Vallvey, Avidad, Fernández-Ramos, \& Ariza-Avidad, 2002), the results from matching the test strip to the colour chart is subjective and the detection limit is not as low as compared to other standard methods.

\section{Methods}

\section{Sampling Techniques:}

A $10 \mathrm{~L}$ well water sample was measured for nitrate/nitrate over 3 time periods (day 0, day 3 and day 31) with HACH test strips (Hach, 2014) and Dionex ICS-2000 Ion Chromatography. At approximately day 3 the sample was measured again with test strips and ion chromatography simultaneously. On day 31 the same testing procedures as on day 3 was repeated.

\section{Standard Methods 4110B for N/N procedure:}

Ion chromatography is a proven method for the determination of nitrate and nitrite in water. The $21^{\text {st }}$ edition of Standard Methods for The Examination of Water and Wastewater includes method 4110 B entitled "Ion Chromatography with Chemical Suppression of Eluent Conductivity” (Standard Methods, 2005) for the use of ion chromatography to determine such anions and is approved by the US Environmental Protection Agency (EPA). The 
methods that include ion chromatography (IC) used for the determination of nitrate and nitrite in water are EPA Test Method 300.0 and Standard Method (SM) 4110 B.

\section{Reliability and validity of measures}

Reliability was ensured with low detection limits, R square value was greater than $95 \%$ for calibration curves, consistency in carrying out procedure, and with a consistent homogeneous representative sample. Validity was ensured with secondary standards, replicates and blank solutions.

\section{Calibration of instruments}

With multiple dilutions and multiple chromatograms, the integration (area under each peak representing an anion) as a function of known concentration to calibrate the ion chromatography was plotted. Once calibrated with known standards it was used to quantitatively determine the concentration of ions of interest in environmental samples. It was standard practice to calibrate the instrument with a multi-ion standard containing anions such as $\mathrm{NO}_{2}^{-}, \mathrm{Br}^{-}, \mathrm{Cl}^{-}$, $\mathrm{F}^{-}, \mathrm{NO}_{3}{ }^{-}, \mathrm{PO}_{4}{ }^{3-}$, and $\mathrm{SO}_{4}{ }^{2-}$.

\section{Sampling}

Sampling was done on December $16^{\text {th }}$ 2013. One large 10L single fresh environmental sample with measurable amounts of nitrate and nitrite was taken from the well where all the tests were to be conducted on it over a period of time. Permission was granted to use well water from a private residence home with the address of 2648813 Ave Langley BC that was drawing water from the Abbotsford Sumas. The well tag no. was 77794 with a well depth of $171 \mathrm{~m}$, diameter of $6 \mathrm{~m}$ water depth of $30 \mathrm{~m}$. To confirm that the well was drawing from this aquifer the address was cross referenced to BC's ground water well and aquifer database. Soon after sampling commenced, analysis began immediately with test strips and ion chromatography. The data collected was then analyzed for the research project.

\section{Results}

\section{Description of data type}

The type of data that was measured was numerical. This was because the concentration of nitrate and nitrate were concentrations and was measured in $\mathrm{mg} / \mathrm{L}$ or parts per million (ppm). Concentrations were measured on a continuum.

\section{Descriptive statistics}

Utilizing NCSS 9 (Hintze, J., 2013) descriptive statistics and Excel (Microsoft, 2007) for data input, results were produced from the ion chromatography data for nitrates and nitrites for both day 3 and 31. Similarly, respective data was produced with test strip data with the addition for day 0 . The mean and standard deviation for the data for each data set were shown in the tables below:
Table 1: Ion chromatography nitrate and nitrite concentrations

\begin{tabular}{|l|l|l|l|l|l|l|}
\hline & $\begin{array}{l}{\left[\mathrm{NO}_{3}\right]} \\
\text { day 0 }\end{array}$ & $\begin{array}{l}{\left[\mathrm{NO}_{3}\right]} \\
\text { day 3 }\end{array}$ & $\begin{array}{l}{\left[\mathrm{NO}_{3}\right]} \\
\text { day 31 }\end{array}$ & {$\left[\mathrm{NO}_{2}\right]$ day 0 } & $\begin{array}{l}{\left[\mathrm{NO}_{2}\right]} \\
\text { day 3 }\end{array}$ & $\begin{array}{l}{\left[\mathrm{NO}_{2}\right]} \\
\text { day 31 }\end{array}$ \\
\hline Mean & 1.17 & 1.15 & 1.13 & $\begin{array}{l}<\text { Detection } \\
\text { Limit (DL) }\end{array}$ & $<\mathrm{DL}$ & $<\mathrm{DL}$ \\
\hline StdDev & 0.047 & 0.027 & 0.013 & $\mathrm{~N} / \mathrm{A}$ & $\mathrm{N} / \mathrm{A}$ & $\mathrm{N} / \mathrm{A}$ \\
\hline Variance & 0.0022 & 0.00073 & 0.00016 & $\mathrm{~N} / \mathrm{A}$ & $\mathrm{N} / \mathrm{A}$ & $\mathrm{N} / \mathrm{A}$ \\
\hline Stderror & 0.0087 & 0.0049 & 0.0023 & $\mathrm{~N} / \mathrm{A}$ & $\mathrm{N} / \mathrm{A}$ & $\mathrm{N} / \mathrm{A}$ \\
\hline Mode & $\mathrm{N} / \mathrm{A}$ & $\mathrm{N} / \mathrm{A}$ & $\mathrm{N} / \mathrm{A}$ & $\mathrm{N} / \mathrm{A}$ & $\mathrm{N} / \mathrm{A}$ & $\mathrm{N} / \mathrm{A}$ \\
\hline Median & 1.17 & 1.16 & 1.13 & $\mathrm{~N} / \mathrm{A}$ & $\mathrm{N} / \mathrm{A}$ & $\mathrm{N} / \mathrm{A}$ \\
\hline Range & 0.19 & 0.085 & 0.049 & $\mathrm{~N} / \mathrm{A}$ & $\mathrm{N} / \mathrm{A}$ & $\mathrm{N} / \mathrm{A}$ \\
\hline Minimum & 1.09 & 1.10 & 1.10 & $\mathrm{~N} / \mathrm{A}$ & $\mathrm{N} / \mathrm{A}$ & $\mathrm{N} / \mathrm{A}$ \\
\hline Maximum & 1.28 & 1.18 & 1.15 & $\mathrm{~N} / \mathrm{A}$ & $\mathrm{N} / \mathrm{A}$ & $\mathrm{N} / \mathrm{A}$ \\
\hline Count & 30 & 30 & 30 & 30 & 30 & 30 \\
\hline
\end{tabular}

Table 2: Test strip nitrate and nitrite concentrations

\begin{tabular}{|l|l|l|l|l|l|l|}
\hline & $\begin{array}{l}{\left[\mathrm{NO}_{3}\right]} \\
\text { day 0 }\end{array}$ & $\begin{array}{l}{\left[\mathrm{NO}_{3}\right]} \\
\text { day 3 }\end{array}$ & $\begin{array}{l}{\left[\mathrm{NO}_{3}\right]} \\
\text { day 31 }\end{array}$ & $\begin{array}{l}{\left[\mathrm{NO}_{2}\right]} \\
\text { day 0 }\end{array}$ & $\begin{array}{l}{\left[\mathrm{NO}_{2}\right]} \\
\text { day 3 }\end{array}$ & $\begin{array}{l}{\left[\mathrm{NO}_{2}\right]} \\
\text { day 31 }\end{array}$ \\
\hline Mean & $<\mathrm{DL}$ & $<\mathrm{DL}$ & $<\mathrm{DL}$ & $<\mathrm{DL}$ & $<\mathrm{DL}$ & $<\mathrm{DL}$ \\
\hline StdDev & $\mathrm{N} / \mathrm{A}$ & $\mathrm{N} / \mathrm{A}$ & $\mathrm{N} / \mathrm{A}$ & $\mathrm{N} / \mathrm{A}$ & $\mathrm{N} / \mathrm{A}$ & $\mathrm{N} / \mathrm{A}$ \\
\hline Variance & $\mathrm{N} / \mathrm{A}$ & $\mathrm{N} / \mathrm{A}$ & $\mathrm{N} / \mathrm{A}$ & $\mathrm{N} / \mathrm{A}$ & $\mathrm{N} / \mathrm{A}$ & $\mathrm{N} / \mathrm{A}$ \\
\hline Stderror & $\mathrm{N} / \mathrm{A}$ & $\mathrm{N} / \mathrm{A}$ & $\mathrm{N} / \mathrm{A}$ & $\mathrm{N} / \mathrm{A}$ & $\mathrm{N} / \mathrm{A}$ & $\mathrm{N} / \mathrm{A}$ \\
\hline Mode & $\mathrm{N} / \mathrm{A}$ & $\mathrm{N} / \mathrm{A}$ & $\mathrm{N} / \mathrm{A}$ & $\mathrm{N} / \mathrm{A}$ & $\mathrm{N} / \mathrm{A}$ & $\mathrm{N} / \mathrm{A}$ \\
\hline Median & $\mathrm{N} / \mathrm{A}$ & $\mathrm{N} / \mathrm{A}$ & $\mathrm{N} / \mathrm{A}$ & $\mathrm{N} / \mathrm{A}$ & $\mathrm{N} / \mathrm{A}$ & $\mathrm{N} / \mathrm{A}$ \\
\hline Range & $\mathrm{N} / \mathrm{A}$ & $\mathrm{N} / \mathrm{A}$ & $\mathrm{N} / \mathrm{A}$ & $\mathrm{N} / \mathrm{A}$ & $\mathrm{N} / \mathrm{A}$ & $\mathrm{N} / \mathrm{A}$ \\
\hline Minimum & $\mathrm{N} / \mathrm{A}$ & $\mathrm{N} / \mathrm{A}$ & $\mathrm{N} / \mathrm{A}$ & $\mathrm{N} / \mathrm{A}$ & $\mathrm{N} / \mathrm{A}$ & $\mathrm{N} / \mathrm{A}$ \\
\hline Maximum & $\mathrm{N} / \mathrm{A}$ & $\mathrm{N} / \mathrm{A}$ & $\mathrm{N} / \mathrm{A}$ & $\mathrm{N} / \mathrm{A}$ & $\mathrm{N} / \mathrm{A}$ & $\mathrm{N} / \mathrm{A}$ \\
\hline Count & 30 & 30 & 30 & 30 & 30 & 30 \\
\hline
\end{tabular}

\section{Inferential statistics}

Scenarios 1 through 4 utilized the one way analysis of variance, ANOVA.

Table 3: Null and Alternate Hypothesis for one way analysis of variance ANOVA

\begin{tabular}{|l|l|l|}
\hline & $\mathbf{H}_{\mathbf{0}}:$ & $\mathbf{H}_{\mathbf{1}}:$ \\
\hline Scenario & {$\left[\mathrm{NO}_{3}\right]_{\mathrm{TS}-\mathrm{T} 0}=\left[\mathrm{NO}_{3}\right]_{\mathrm{TS}-}$} & {$\left[\mathrm{NO}_{3}\right]_{\mathrm{TS}-\mathrm{T} 0} \neq\left[\mathrm{NO}_{3}\right]_{\mathrm{TS}-}$} \\
1 & $\mathrm{~T}=\left[\mathrm{NO}_{3}\right]_{\mathrm{TS}-\mathrm{T} 31}$ & $\mathrm{~T} 3 \neq\left[\mathrm{NO}_{3}\right]_{\mathrm{TS}-\mathrm{T} 31}$ \\
\hline Scenario & {$\left[\mathrm{NO}_{2}\right]_{\mathrm{TS}-\mathrm{T} 0}=\left[\mathrm{NO}_{2}\right]_{\mathrm{TS}-}$} & {$\left[\mathrm{NO}_{2}\right]_{\mathrm{TS}-\mathrm{T} 0} \neq\left[\mathrm{NO}_{2}\right]_{\mathrm{TS}-}$} \\
2 & $\mathrm{~T} 3=\left[\mathrm{NO}_{2}\right]_{\mathrm{TS}-\mathrm{T} 31}$ & $\mathrm{~T} 3 \neq\left[\mathrm{NO}_{2}\right]_{\mathrm{TS}-\mathrm{T} 31}$ \\
\hline Scenario & {$\left[\mathrm{NO}_{3}\right]_{\mathrm{IC}-\mathrm{T} 0}=\left[\mathrm{NO}_{3}\right]_{\mathrm{IC}-}$} & {$\left[\mathrm{NO}_{3}\right]_{\mathrm{IC}-\mathrm{T} 0} \neq\left[\mathrm{NO}_{3}\right]_{\mathrm{IC}-}$} \\
3 & $\mathrm{~T} 3=\left[\mathrm{NO}_{3}\right]_{\mathrm{IC}-\mathrm{T} 31}$ & $\mathrm{~T}=\left[\mathrm{NO}_{3}\right]_{\mathrm{IC}-\mathrm{T} 31}$ \\
\hline Scenario & {$\left[\mathrm{NO}_{2}\right]_{\mathrm{IC}-\mathrm{T} 0}=\left[\mathrm{NO}_{2}\right]_{\mathrm{IC}-}$} & {$\left[\mathrm{NO}_{2}\right]_{\mathrm{IC}-\mathrm{T} 0} \neq\left[\mathrm{NO}_{2}\right]_{\mathrm{IC}-}$} \\
4 & $\mathrm{~T} 3=\left[\mathrm{NO}_{2}\right]_{\mathrm{IC}-\mathrm{T} 31}$ & $\mathrm{~T} 3 \neq\left[\mathrm{NO}_{2}\right]_{\mathrm{IC}-\mathrm{T} 31}$ \\
\hline
\end{tabular}

*where TS denotes test strip, IC denotes ion chromatography,

*where T0, T3 and T31 denotes day 0, 3 and 31 respectively

*where [NO3] and [NO2] are mean values

\section{Statistical package}

The statistical package utilized to calculate one way analysis of variance ANOVA results for the scenarios above is NCSS 9.

\section{Interpretation of results}

The data for scenario 3 was determined to be parametric since there was no rejection of normality as shown from the 
results; therefore, the "Normal-Scores Tests" was used. The result from ANOVA table shows $\mathrm{p}=0.000011$ (or $\mathrm{P}<0.05$ ) and a power of $99.7 \%$. This implies that $\mathrm{H}_{0}$ : $\left[\mathrm{NO}_{3}\right]_{\text {IC-T0 }}=$ $\left[\mathrm{NO}_{3}\right]_{\text {IC-T3 }}=\left[\mathrm{NO}_{3}\right]_{\text {IC-T31 }}$ must be rejected and thus $\mathrm{H}_{\mathrm{A}}$ should be accepted that there is a statistically significant difference between all the mean concentrations of nitrate. Since probability value is 0.000011 or $\mathrm{P}<0.05$ it is not necessary to consider alpha and beta errors.

Since the ANOVA findings were significant (i.e. $\mathrm{p}<$ 0.05 where $\mathrm{P}=0.00011$ in this case) the Scheffe's MultipleComparison Test was used. It was found that nitrate at time zero using the ion chromatography EPA method was different from all groups. In addition, it was found that the nitrate concentrations found using the ion chromatography on day 3 and 31 were statistically not different; however, the nitrate concentrations found using ion chromatography on the day 3 and 31 were statistically different than what was found on day 0 .

Table 4: ANOVA tabulated Results

\begin{tabular}{|c|c|c|c|}
\hline Null Hypotheses (Ho) & $\begin{array}{c}\text { Probability } \\
\text { level } \\
(\mathbf{p}<\mathbf{0 . 0 5})\end{array}$ & $\begin{array}{c}\text { Power } \\
\mathbf{( \% )}\end{array}$ & Analysis \\
\hline $\begin{array}{c}\text { There is no difference } \\
\text { in [NO3] using test } \\
\text { strips between day 0, } \\
\text { and 31. }\end{array}$ & N/A & N/A & N/A \\
\hline $\begin{array}{c}\text { There is no difference } \\
\text { in [NO2] using test } \\
\text { strips between day 0, 3 } \\
\text { and 31. }\end{array}$ & N/A & N/A & N/A \\
\hline $\begin{array}{c}\text { There is no difference } \\
\text { in [NO3] using IC } \\
\text { between day 0, 3 and } \\
\text { 31. }\end{array}$ & $\mathbf{0 . 0 0 0 0 1 1}$ & $\mathbf{9 9 . 7}$ & $\begin{array}{c}\text { Reject } \\
\text { Ho }\end{array}$ \\
\hline $\begin{array}{c}\text { There is no difference } \\
\text { in [NO2] using IC } \\
\text { between day 0, 3 and } \\
\text { 31. }\end{array}$ & N/A & N/A & N/A \\
\hline
\end{tabular}

\section{Discussion}

Previous research done at BCIT found that boiling water increased the concentration of nitrates found in drinking water (Cranch, 2005). However, the change in nitrate concentrations found in this research project suggests that nitrate concentration can also change over time without boiling. Although it was not determined what had caused the change the fact that it had changed in cold storage over time is an issue to consider when analyzing drinking water samples nitrate concentrations. Whether it is drinking water samples that have been sitting passed their holding times or samples that have been boiled, both are not going to be representative samples.
The Analysis of Variance test, ANOVA, was the statistical analysis selected to determine if there was a statistical difference between test strips and the standard ion chromatography EPA method when determining nitrate/nitrite concentrations in the well water sample. However, since the test strips were unable to detect the levels of nitrate/nitrite in the water and with the nitrite levels being too low for the ion chromatography method it was not possible to evaluate scenarios 1,2 and 4 since the variables involved in the ANOVA for these scenarios were related to the non-ideal results. Thus no further analysis could have been done.

Although there were statistically significant differences between nitrate levels found in the well water sample between the day 0, 3 and 31, this difference would not be of significant public health concern. The difference is minimal with the mean shifting from 1.17 to $1.13 \mathrm{mg} / \mathrm{L}$ nitrate as $\mathrm{N}$ in the well water sample over 31 days. This minimal difference does technically mean that concentration of nitrate will change over time which would justify the rationale for BC's MOE holding times. However, since the MAC value is listed as $10 \mathrm{mg} / \mathrm{L}$ nitrate as $\mathrm{N}$, the difference in $0.04 \mathrm{mg} / \mathrm{L}$ would have not been large enough to significantly change concentrations of samples near the MAC value if the sample was tested for nitrate 31 days after it was sampled assuming this research study results can be generalized. Thus, if a well water nitrate test sample had passed MOE holding times it would still yield an acceptable result from a public health standpoint.

The minimum requirement for water to be deemed potable by a health officer is by ensuring that the water passes bacteriological tests from an approved laboratory since current regulations in BC's DWPR, Schedule A, entitled "Water Quality Standards for Potable Water" under the DWPA only states microbiological parameters for drinking water (DWPR, 2013). Current routine practice for well water testing through health authorities in BC, if provided to the public, is a bacteriological test that is usually contracted out to BCCDC water laboratories which do not include chemical tests such as nitrate. Nitrate testing in BC for private drinking well water systems is not legally required. Furthermore, if a standardized nitrate test is requested in addition to the minimum required bacteriological test for a drinking water sample, then there is generally low probability of going over MOE holding times for nitrate since the bacteriological holding time for drinking water is 30 hours which is less than MOE holding time for nitrate.

\section{Recommendations}

To address the limitations of detecting nitrite in this study, one could find a water sample with a known amount of nitrite. To ensure this, a diagnostic test using a test strip on 
drinking water wells could be done before selecting the actual test well.

\section{Limitations}

A possible limitation would be if the sample had been boiled prior to analysis. This would have caused a positive bias in the results. Since the sample was not boiled there would have been no increase in the nitrate concentration caused by boiling.

Test strips were unable to detect the concentration of nitrate/nitrite in the drinking water sample used in this research study. This was because the concentrations of nitrate/nitrite were too low for the test strips to detect. The test strips range for nitrate was $0-50 \mathrm{mg} / \mathrm{L}$ as $\mathrm{N}$ which is a useful range since the MAC level falls within this range at $10 \mathrm{mg} / \mathrm{L}$ nitrate as $\mathrm{N}$. Although the results found by the IC ranged from 1.13 to $1.17 \mathrm{mg} / \mathrm{L}$ the test strips failed to detect nitrate even though the values were within the test strips range. The test strip changes color from clear to pink when dipped into water with nitrate in it. The amount of nitrate in the water is correlated to the intensity of the colour pink found on the test strip. The colour that was observed at time of the experiment was that of no colour change. Since this observation was conducted by visually it was subject to human error as the perception of seeing colour between individuals may vary. In this case the intensity of pink may have been so low that it may have been easily mistaken as no colour change which correlates to a value less than the detection limit of the test strip. The results from this research study did not invalidate the use of test strips for use public health applications since they are just a diagnostic tool. Test strips are useful to give a general idea of the concentration of nitrate. However, if the nitrate concentration is near the MAC level an EPA method should be used to determine if it is greater or less than the MAC level.

Unfortunately due to the initial low nitrate/nitrite concentration of the well water sample, the data was not constructive in the evaluation of most of the generated hypotheses of this research study. By having data of detectable levels of nitrate/nitrite, then a statistically significant difference between test strips and the standard ion chromatography EPA method could have been determined.

What had caused a decrease in the amount of nitrate observed in the environmental sample over time was unknown. The change of nitrate over time may have been due to some chemical and biological activity that had occurred in the sample. Since environmental samples infinitely vary in chemical and biological composition from each other it is impossible to determine what had caused nitrate to decrease.

\section{Future Studies}

Although nitrate can be associated to E.coli because both indicate contamination of fecal matter, the direct link between E.coli and nitrates could be studied. The following studies could help with understanding this link:

i. Repeat the experiment using a known nitrate or nitrite standard solution and examine if there is any change in this concentration over time.

ii. Repeat the experiment using a known nitrate or nitrite standard solution spiked with E.coli and examine if there is any change in this concentration over time.

\section{Conclusion}

The MOE holding times are justified because the concentrations were statistically significant $(p=0.0001)$ from day 0 to day 31 from the sampling date indicating a change of concentration of the chemical due to time. However, the difference was not of a magnitude that may impact public health practices/policies. In addition to previous BCIT research findings that there was an increase in nitrate concentrations due to boiling, simply holding the sample in cold storage for a period of time changed nitrate concentrations. Future studies of nitrate concentrations with respect to chemical and biological components in water may lead to a greater understanding of its change in the environment and thus its association with other potential health hazards.

\section{Acknowledgement}

"The author would like to thank Kevin Soulsbury of the BCIT Chemistry Department for his guidance, supervision and permission to use the Chemistry laboratory for this research. He has truly gone above and beyond the call of duty and should be recognized for this because without him the methodology could not have come into fruition. Thank you Kevin."

\section{Competing Interest}

"The authors declare that they have no competing interests"

\section{References}

Abeliovich A. (2007). The Prokaryotes: The NitriteOxidizing Bacteria (pp. 861 - 872). New York, NY: Springer Science.

APHA, AWWA, and WEF (2005). Standard Methods for the Examination of Water and Wastewater: Determination of Anions By Ion Chromatography Method 4110. $21^{\text {st }}$ ed Washington, D.C: APHA, AWWA, and WEF. 
Aquacheck (2013). Aquachek-nitratenitrite. Retrieved from http://www.aquachek.com/distributor/aquacheknitratenitrite/

Archer, M.C. (1989). Mechanisms of action of N-nitroso compounds. Cancer Surveys, 8(2), 241 - 250.

Avery, A. A. (1999). Infantile Methemoglbinemia: Reexamining the role of Drinking Water. Journal is Environmental Health Perspectives, 107, number 7.

Badawi, A. F. (2000).Nitrate, nitrite and N-nitroso compounds in human bladder cancer associated with schistosomiasis. International journal of cancer, 86(4), $598-600$.

Capitán-Vallvey, L. F. Avidad R. Fernández-Ramos, M. D. Ariza-Avidad, A. Arroyo, E. (2002). Test strip for determination of nitrite in water. Anal Bioanal Chem, 373, 289-294

Cambridge Times. (2007, October). Well owners need to test water more, says resource manager. Cambridge Times, Retrieved from: http://www.cambridgetimes.ca/news-story/3371970-wellowners-need-to-test-water-more-says-resource-manager/

CDC (2010). Well Testing. Retrieved from http://www.cdc.gov/healthywater/drinking/private/wells/t esting.html

Chang, R., Cruickshank, B. (2005). Chemistry Eighth Edition. New York, NY: McGraw-Hill.

City of Abbotsford (2014). Ground Water. Retrieved from http://www.abbotsford.ca/economic_development_and_pl anning_services/environment/air_water/ground_water.ht $\mathrm{m}$

Comly H.H. (1945). Cyanosis in infants caused by nitrates in well water. The Journal of the American Medical Association, 129, 112-116.

Cranch J. (2005). The Effects of Boiling Water on Nitrate Concentration. BCIT

Dionex (2008). ICS-2000 Ion Chromatography System. Retrieved from http://www.dionex.com/enus/webdocs/4279DS_ICS_2000_22Jul08_LPN1500_07.pdf

Drinking Water Protection Act. (2013). BC Laws. Retrieved from:http://www.bclaws.ca/EPLibraries/bclaws_new/doc ument/ID/freeside/00_01009_01

Drinking Water Protection Act: Drinking Water Protection Regulation. (2013). BC Laws, Schedule A. Retrieved from:
http://www.bclaws.ca/EPLibraries/bclaws_new/document /ID/freeside/200_2003\#ScheduleA

Drinking Water Protection Act: Drinking Water Protection Regulation. (2013). BC Laws, Schedule B. Retrieved from:

http://www.bclaws.ca/EPLibraries/bclaws_new/document /ID/freeside/200_2003\#ScheduleB

Environmental Management Act: Contaminated Sites Regulation. (2013). BC Laws, Schedule 6. Retrieved from:

http://www.bclaws.ca/EPLibraries/bclaws_new/document /ID/freeside/375_96_08

EPA, Revision 2.1, August 1993, Method 300.0, Determination of Inorganic Anions by Ion Chromatography, Pages 300.0-1 to 300.0-29.

Hach (2014). Nitrite and Nitrite Test Strips. Retrieved from http://www.hach.com/nitrate-and-nitrite-teststrips/product-details?id=7640211606

Health Canada (2012). Guidelines for Canadian Drinking Water Quality—Summary Table. Water, Air and Climate Change Bureau, Healthy Environments and Consumer Safety Branch, Health Canada, Ottawa, Ontario. Retrieved November 25, 2013, from http://www.hc-sc.gc.ca/ewhsemt/alt_formats/pdf/pubs/water-eau/2012-sum_guideres_recom/2012-sum_guide-res_recom-eng.pdf

Hintze, J. (2013). NCSS 9. NCSS, LLC. Kaysville, Utah, USA. www.ncss.com.

Isaacson, P. G. Wotherspoon, A. C. Ortiz-Hidalgo, C. Falzon, M. R. (1991). Helicobacter pylori-associated gastritis and primary B-cell gastric lymphoma. Lancet, 338( 8776), 1175 - 1176.

Lukens, J. N. (1987). The Legacy of Well-Water Methemoglobinemia. The journal of the American Medical Association, 257, 2793 - 2795.

Maze E. (2007). Arsenic in Drinking Water: Does Boiling arsenic contaminated water significantly concentrate arsenic levels. BCIT

McKnight, G. M. Duncan, C. W. Leifert, C. Golden, M. H. (1999). Dietary nitrate in man: friend or foe? British Journal of Nutrition, 81(5), 349 - 358.

Microsoft. (2007). Microsoft Excel (Version 2007). Microsoft Corporation.

Ministry of Environment (2007). Nitrate in Groundwater. Retrieved from http://www.env.gov.bc.ca/wsd/plan_protect_sustain/groun 
dwater/library/ground_fact_sheets/pdfs/no3(020715)_fin2 .pdf

Mitchell, R. (2004) Nitrate in the Abbotsford-Sumas Aquifer, British Columbia and Northwest Washington State [PowerPoint slides]. Retrieved from http://kula.geol.wwu.edu/rjmitch/absumas_2.pdf

Mostafa, M. H. Sheweita, S. A. O'Connor, P. J. (1999). Relationship between Schistosomiasis and Bladder Cancer. Clinical Microbiology Reviews, 12(1), 97 - 111.

Public Health Act. (2013). BC Laws. Retrieved from: http://www.bclaws.ca/EPLibraries/bclaws_new/document /ID/freeside/00_08028_01

Standard Methods for the Examination of Water and Wastewater, $21^{\text {st }}$ edition, 2005, Method 4110 pages 4-3 to 4-5.

United States Environmental Protection Agency. (2011, June). Approved methods for inorganic chemicals and other parameters. Retrieved November 11 2013, from http://water.epa.gov/scitech/drinkingwater/labcert/upload/ methods_inorganic.pdf

Ward, M. H., deKok, T. M., Levallois P., Brender, J., Gulis, G., Nolan, B.T., VanDerslice, J.

(2005). Workgroup Report: Drinking-water Nitrate and Health - REcent Findings and Research needs.

Environmental Health Perspectives, 113(11), 1607 - 1614.

Wolfe, D. W. (2001). Tales from the underground: a natural history of subterranean life. United States of America:

Basic Books.

World Health Organization (2011). Nitrate and nitrite in drinking-water. Retrieved from

http://www.who.int/water_sanitation_health/dwq/chemica ls/nitratenitrite2ndadd.pdf 